\title{
ANALISIS HUBUNGAN PENDAPATAN WISATAWAN DAN HARGA PARIWISATA TERHADAP PERMINTAAN PARIWISATA DENGAN VECM
}

\author{
Merary Sianipar $^{\S 1}$, Ni Luh Putu Suciptawati ${ }^{2}$, Komang Dharmawan ${ }^{3}$ \\ ${ }^{1}$ Jurusan Matematika, Fakultas MIPA - Universitas Udayana [Email: merarysianipar@ gmail.com] \\ ${ }^{2}$ Jurusan Matematika, Fakultas MIPA - Universitas Udayana [Email: putusucitawati@yahoo.co.id] \\ ${ }^{3}$ Jurusan Matematika, Fakultas MIPA - Universitas Udayana [Email: k.dharmawan@unud.ac.id] \\ ${ }^{\S}$ Corresponding Author
}

\begin{abstract}
Tourism demand is focused on estimating variables which influence tourist visit. The tourism demand that we discuss on this research is the tourism demand to Bali of the major tourism-generating country was Australia. The aim of this research is to analyze the relationship between tourist income and tourism price to tourism demand using VECM. VECM requires that the variables in the model must be stationary and fulfilled a cointegration condition. In order to make it valid, the stationarity of variables in the model have to be checked using ADF unit root test. In additon, cointegration between these variables are examined using Johansen's cointegration test. The results of ADF unit root test show that indicated the tourist income, the tourism price and the tourism demand for Australia data are stationary in first lag or I(1). Cointegration test shows that all variables are cointegrated, i.e. have a long-run relationship. In the long-run, the tourist income and tourism price give positive effect to the tourism demand. This means, the increase of tourist income and tourism price will contribute to the increase in tourism demand. In addition, in the short-run, the tourist income and the tourism price give negative effect to the tourism demand. This means, the increase of tourist income and tourism price will contribute to the decrease in tourism demand.
\end{abstract}

Keywords: ADF Unit Root Test, Johansen's Cointegration Test, The Tourism Demand, The Tourist Income, The Tourism Price, Vector Error Correction Model.

\section{PENDAHULUAN}

Menurut teori ekonomi, permintaan suatu barang merupakan fungsi dari pendapatan dan harga barang tersebut dan barang lainnya. Demikian juga halnya, permintaan pariwisata juga dipengaruhi oleh pendapatan wisatawan dan harga pariwisata (Stabler \& Sinclair [9]). Mengingat bahwa kedatangan wisatawan mencakup urusan bisnis dan rekreasi, Produk Domestik Bruto (PBD) negara asal wisman digunakan sebagai variabel pendapatan. Selain itu, dikarenakan sulitnya mendapatkan angka tunggalnya, harga pariwisata dapat direpresentasikan oleh Indeks Harga Konsumen relatif, yaitu Indeks Harga Konsumen negara tujuan dibagi dengan nilai tukar mata uang kedua negara dibagi dengan Indeks Harga Konsumen negara asal wisatawan (Song \& Li [8]).

Metode yang dapat digunakan untuk menganalisis pengaruh pendapatan wisatawan dan harga pariwisata terhadap permintaan pariwisata adalah model Vector Autoregressive (VAR). Menurut Sims [7], variabel-variabel yang diamati tersebut perlu diberi perlakuan yang sama jika memang terdapat hubungan simultan antarvariabel, sehingga tidak ada lagi variabel endogen dan eksogen. Di sisi lain, variabel permintaan pariwisata, pendapatan wisatawan dan harga pariwisata merupakan variabel-variabel runtun waktu yang bersifat nonstasioner dan diduga adanya kemungkinan berkointegrasi, sehingga model VAR kurang 
cocok digunakan. Analisis yang lebih layak digunakan untuk variabel pendapatan wisatawan dan harga pariwisata yang mempunyai sifat nonstationer dan adanya kointegrasi adalah Vector Error Correction Model (VECM). VECM merupakan bentuk dari VAR yang terestriksi. Pada penelitian ini VECM digunakan untuk melihat keseimbangan jangka pendek pada variabel pendapatan wisatawan dan harga pariwisata terhadap permintaan pariwisata.

Suatu proses stokastik dikatakan stasioner jika mean dan variansnya konstan dari waktu ke waktu, serta nilai kovarians antara dua periode waktu tergantung dari jarak (lag) antara kedua periode waktu itu $\left(y_{t}, y_{t+k}\right)$. Misalnya, titik awal $y$ digeser dari $y_{t}$ ke $y_{t+k}$ maka $y$ dikatakan stasioner apabila rata-rata, varians, dan kovarians dari $y_{t+k}$ sama dengan rata-rata, varians, dan kovarians $y_{t}$.

Menurut Enders [3], apabila dilakukan analisis pada data yang tidak stasioner, maka akan memberikan hasil regresi yang palsu (spurious regression). Dengan kata lain, data runtun waktu yang diuji tersebut haruslah stasioner, dan apabila data tidak stasioner maka harus dilakukan transformasi kestasioneran melalui proses differencing. Differencing dilakukan untuk mentransformasi data runtun waktu yang tidak stasioner agar menjadi stasioner (Box \& Jenkins [1]). Menurut Gujarati [5], proses differencing dapat dirumuskan:

$$
\Delta y_{t}=y_{t}-y_{t-1}
$$

dengan $\Delta$ adalah operator differencing; $y_{t}$ menyatakan pengamatan pada waktu $t$. Suatu data runtun waktu yang tidak stasioner tetapi menjadi stasioner setelah di-defferencing $d$ kali, maka dikatakan terintegrasi pada orde $d$, disingkat $I(d)$, yang berarti data tersebut mengandung $d$ akar unit.

Metode yang dapat digunakan untuk menguji kestasioneran data adalah dengan pengujian akar unit (unit root test). Teknik pengujian unit root adalah dengan membentuk regresi antara $\Delta y_{t}$ dan $y_{t-1}$. Uji akar unit yang popular digunakan adalah uji Augmented Dickey-Fuller (ADF test). Dickey dan Fuller [2] mengembangkan uji Augmented Dickey-Fuller (ADF test) untuk menguji adanya keberadaan unit root dalam suatu variabel pada model $A R$ dengan order lebih dari satu atau $(A R(p))$. Dalam uji akar unit ADF, residual pada model diasumsikan berautokorelasi atau mempunyai hubungan. Model regresi yang akan digunakan untuk melakukan uji akar unit ADF, yaitu:

$$
\Delta y_{t}=\mu+\delta y_{t-1}+\sum_{i=1}^{m} \alpha_{i} \Delta y_{t-i}+u_{t}
$$

dengan $\delta=\sum_{i=1}^{p} \phi_{i}-1, \alpha_{i}=-\sum_{j=i+1}^{m} \phi_{j}, u_{t}$ menyatakan suatu residual, dan $m=p-1$ adalah panjang lag. Bentuk hipotesis untuk uji kestasioneran menurut uji akar unit ADF adalah:

$H_{0}: \delta=0$ (memiliki akar unit/tidak stasioner), $H_{1}: \delta<0$ (tidak memiliki akar unit/stasioner). Statistik uji $\tau$ diperoleh dengan

$$
\tau=\frac{\sum_{i=1}^{p} \phi_{i}-1}{\text { std.error }\left(\sum_{i=1}^{p} \widehat{\phi}_{i}\right)}
$$

Aturan keputusan:

Jika nilai statistik uji $\tau$ lebih kecil dari nilai kritis tabel DF atau tabel MacKinnon maka hipotesis nol ditolak yang berarti data runtun waktu bersifat stasioner, sedangkan jika nilai statistik uji $\tau$ lebih besar dari nilai kritis DF atau MacKinnon maka hipotesis nol tidak ditolak yang berarti data runtun bersifat nonstasioner.

Vector Autoregressive atau yang dikenal dengan VAR biasanya digunakan untuk menganalisis hubungan sistem variabel-variabel runtun waktu dan menganalisis dampak dinamis dari faktor gangguan yang terdapat dalam variabel tersebut. Pada dasarnya analisis VAR bisa dipadankan dengan suatu model persamaan simultan karena dalam analisis VAR mempertimbangkan beberapa variabel endogen (dependent/terikat) secara bersama-sama dalam suatu model. Selain itu, dalam analisis VAR biasanya tidak ada variabel eksogen (independent/bebas) dalam model tersebut.

Secara umum, bentuk VAR dengan banyaknya variabel $n$ dan jumlah lag $p$ dimodelkan sebagai berikut:

$$
\begin{aligned}
\boldsymbol{y}_{t}= & \boldsymbol{A}_{0}+\boldsymbol{A}_{1} \boldsymbol{y}_{t-1}+\boldsymbol{A}_{2} \boldsymbol{y}_{t-2}+\cdots+ \\
& \boldsymbol{A}_{p-1} \boldsymbol{y}_{t-p+1}+\boldsymbol{A}_{p} \boldsymbol{y}_{t-p}+\boldsymbol{u}_{t}
\end{aligned}
$$


dengan $\quad \boldsymbol{y}_{t}=\left(\begin{array}{lllll}y_{1 t} & y_{2 t} & \ldots & y_{(n-1) t} y_{n t}\end{array}\right)^{\prime}, \quad \boldsymbol{A}_{0}$ adalah matriks konstanta berukuran $(n \times 1), \boldsymbol{A}_{i}$ adalah matriks koefisien berukuran $(n \times n)$, $i=1,2, \ldots, p$, dan $\boldsymbol{u}_{t}$ adalah vektor error yang berukuran $(n \times 1)$.

Estimasi VAR/VECM sangat peka terhadap panjang lag yang digunakan. Penentuan lag yang optimal menjadi salah satu prosedur penting yang harus dilakukan dalam pembentukan model. Metode yang dapat digunakan untuk menentukan kriteria panjang lag optimal adalah Akaike Information Criterion (AIC) yang didefinisikan sebagai berikut:

$$
\begin{aligned}
& \ln (A I C) \\
& =\ln \frac{\sum \hat{u}_{i}^{2}}{n}+\frac{2 k}{n}
\end{aligned}
$$

dengan $\sum u_{i}^{2}$ adalah jumlah dari residual kuadrat, $k$ menyatakan jumlah variabel bebas, $n$ menyatakan jumlah observasi. Panjang lag optimal ditentukan oleh nilai AIC yang terkecil. Semakin kecil nilai AIC maka semakin baik model yang digunakan (Tsay [10]).

Kointegrasi berhubungan erat dengan masalah menemukan suatu hubungan jangka panjang atau keseimbangan jangka panjang. Menurut Engle dan Granger [4], apabila data runtun waktu terkointegrasi, maka terdapat suatu hubungan jangka panjang di antara data runtun waktu tersebut. Ide dasar kointegrasi adalah mencari kombinasi linear di antara dua peubah yang terintegrasi pada orde $d$ yang menghasilkan sebuah peubah dengan orde integrasi yang lebih rendah. Jika dua atau lebih peubah, misal $x_{t}$ dan $y_{t}$ nonstasioner, tetapi kombinasi linear dari peubah-peubah tersebut stasioner, maka peubah-peubah tersebut dikatakan terkointegrasi dan dapat representasi khusus sebagai berikut:

$$
\begin{aligned}
& y_{t}=\beta_{0}+\beta_{1} x_{t}+u_{t} \\
& u_{t}=y_{t}-\beta_{0}-\beta_{1} x_{t}
\end{aligned}
$$

sedemikian sehingga $u_{t}$ (error term) stasioner.

Untuk suatu model $\operatorname{VAR}(p)$, yang akan direpresentasikan kedalam bentuk VECM secara umum dapat dinyatakan sebagai:

$$
\Delta \boldsymbol{y}_{t}=\boldsymbol{\Pi} \boldsymbol{y}_{t-1}+\sum_{i=1}^{p-1} \boldsymbol{\Pi}_{i} \Delta \boldsymbol{y}_{t-i}+u_{t} \text {. }
$$

Persamaan (5) mengandung informasi baik penyesuaian jangka pendek dan jangka panjang terhadap perubahan $\boldsymbol{y}_{t}$. Rank matriks $\boldsymbol{\Pi}$ ditandai dengan $r$, menentukan berapa banyak kombinasi linear $\boldsymbol{y}_{t}$ yang bersifat stasioner. Jika $0<r<n$, maka terdapat $r$ vektor kointegrasi atau $r$ kombinasi linear yang stasioner dari $\boldsymbol{y}_{t}$. Dalam kasus ini, $\Pi$ dapat difaktorisasi, sebagai $\boldsymbol{\Pi}=\boldsymbol{\alpha} \boldsymbol{\beta}^{\prime}$, dengan $\boldsymbol{\alpha}$ dan $\boldsymbol{\beta}$ adalah matriks $n \times$ $r$, dengan $\boldsymbol{\alpha}$ mempresentasikan kecepatan penyesuaian terhadap ketidakseimbangan, dan $\boldsymbol{\beta}$ adalah matriks dari koefisien jangka panjang dan mengandung vektor kointegrasi.

Dalam penelitian ini, pengujian kointegrasi dilakukan dengan menggunakan uji kointegrasi Johansen. Uji kointegrasi Johansen umumnya hanya untuk variabel yang terintegrasi pada orde satu dan orde nol, yaitu $I(1)$ dan $I(0)$. Pengujian jumlah hubungan kointegrasi dapat dilakukan dengan trace test. Trace test merupakan uji untuk mengukur jumlah vektor kointegrasi dalam data runtun waktu dengan menggunakan pengujian rank matriks kointegrasi, dinyatakan:

$$
\begin{aligned}
\lambda_{\text {trace }}(r) & \\
& =-T \sum_{i=r+1}^{n} \ln \left(1-\hat{\lambda}_{i}\right)
\end{aligned}
$$

dan

$$
\begin{aligned}
\lambda_{\max }(r, r+1) \\
\quad=-T \ln \left(1-\hat{\lambda}_{r+1}\right)
\end{aligned}
$$

dengan $T$ menyatakan jumlah observasi, $\hat{\lambda}_{i}$ menyatakan estimasi eigenvalue yang dihasilkan dari estimasi matriks $\Pi$, dan $r$ menyatakan rank yang mengindikasikan jumlah vektor kointegrasi. Dengan mengetahui jumlah $r$, maka akan diketahui jumlah hubungan kointegrasi di antara data runtun waktu (Johansen \& Juselius [6]).

Hipotesis pengujian:

$H_{0}$ : banyaknya vektor kointegrasi $(r)=0$

$H_{1}$ : banyaknya vektor kointegrasi $(r)>0$

Aturan keputusan:

apabila nilai trace statistic lebih besar dari nilai kritis pada tingkat kepercayaan $\alpha$ atau nilai probabilitas lebih kecil dari $\alpha$ maka hipotesis nol ditolak yang artinya terjadi kointegrasi. 
Vector Error Correction Model (VECM) adalah pengembangan model VAR untuk runtun waktu yang tidak stasioner dan memiliki satu atau lebih hubungan kointegrasi (Enders [3]). VECM merupakan bentuk dari Vector Autoregressive (VAR) yang terestriksi. Restriksi tambahan ini harus diberikan karena keberadaan bentuk data yang tidak stasioner namun terkointegrasi. Pembentukan representasi secara umum dari VECM diperoleh dengan memanipulasi representasi umum VAR orde $p, \operatorname{VAR}(p)$ pada persamaan (3). Bentuk VECM:

$$
\Delta \boldsymbol{y}_{t}=\boldsymbol{\Pi} \boldsymbol{y}_{t-1}+\sum_{i=1}^{p-1} \boldsymbol{\Pi}_{i} \Delta \boldsymbol{y}_{t-i}+u_{t}
$$

Persamaan (5) dapat diuraikan menjadi

$$
\begin{aligned}
\Delta \boldsymbol{y}_{t} & =\boldsymbol{\Pi}_{0}+\boldsymbol{\Pi} \boldsymbol{y}_{t-1}+\Pi_{1} \Delta \boldsymbol{y}_{t-1}+\Pi_{2} \Delta \boldsymbol{y}_{t-2} \\
& +\cdots+\Pi_{p-1} \Delta \boldsymbol{y}_{t-p+1}+\boldsymbol{u}_{\boldsymbol{t}}
\end{aligned}
$$

dengan $\Pi_{0}$ adalah vektor konstanta yang berukuran $(\mathrm{n} \times 1), \boldsymbol{\Pi}_{i}$ adalah matriks koefisien yang berukuran $(n \times n), \quad \Pi \boldsymbol{y}_{t-1}$ merupakan Error Correction Term (ECT) dan $\boldsymbol{u}_{t}$ adalah vektor white noise $\left(\boldsymbol{u}_{1 t}, \boldsymbol{u}_{2 t}, \ldots, \boldsymbol{u}_{n t}\right)^{\prime}$ yang berukuran $(\mathrm{n} \times 1)$.

Untuk mengetahui VECM merupakan model yang valid, dapat dilihat pada hasil uji statistik terhadap koefisien Error Correction Term (ECT). Jika hasil pengujian terhadap koefisien ECT signifikan, maka dapat di katakan spesifikasi model yang diamati valid. Nilai mutlak koefisien ECT menyatakan lama waktu yang diperlukan untuk kembali ke arah keseimbangannya (Engle \& Granger [4]).

\section{METODE PENELITIAN}

Penelitian ini menggunakan data berupa data sekunder. Dalam hal ini data yang digunakan adalah jumlah kunjungan wisatawan Australia ke Bali yang diperoleh dari situs www.disparda.baliprov.go.id, Produk Domestik Bruto (PBD) Australia yang diperoleh dari situs www.tradingeconomics.com, Indek Harga Konsumen (IHK) Australia dan Indonesia yang diperoleh dari www.abs.gov.au dan www.bps.go.id, serta nilai tukar rupiah terhadap mata uang Australia yang diperoleh dari situs www.bi.go.id. Data-data tersebut merupakan data berbentuk kuartalan, yaitu Kuartal 3 (Q3) 2002 hingga Kuartal 2 (Q2) 2015. Data pada penelitian ini diolah dengan menggunakan software EViews 6.0. Adapun langkah-langkah penelitian ini adalah sebagai berikut: (1) Menguji kestasioneran data pada $n$ variabel runtun waktu dalam orde integrasi di tingkatnya dengan menggunakan uji akar unit ADF; (2) Jika data belum stasioner, perlu dilakukan differencing pertama atau I(1) terhadap variabel runtun waktu; (3) Menguji kembali kestasioneran data pada variabel runtun waktu yang telah differencing pertama atau I(1) dengan menggunakan uji akar unit ADF; (4) Jika data telah stasioner, dilakukan pemilihan panjang lag optimal menggunakan AIC; (5) Menduga matriks $\Pi$ dengan menggunakan $M L E$ sedemikian sehingga akan diperoleh nilai eigen $\hat{\lambda}_{1} \geq \hat{\lambda}_{2} \geq \cdots \geq \hat{\lambda}_{n} ; \quad$ (6) Pengujian jumlah vektor kointegrasi yang diperoleh dari jumlah nilai eigen yang terbentuk dengan menggunakan uji kointegrasi Johansen; (7) Pengujian Vector Error Correction Model (VECM).

\section{HASIL DAN PEMBAHASAN}

Secara konfirmatif, pemeriksaan kestasioneran sebuah variabel dapat diperiksa dengan menggunakan uji akar unit ADF. Setiap variabel yang diuji yaitu: permintaan pariwisata, pendapatan wisatawan, dan harga pariwisata diasumsikan mengikuti persamaan yang dinyatakan sebagai berikut:

$\operatorname{wisman}_{t}=\delta_{1}$ wisman $_{t-1}+\sum_{i=1}^{m} \alpha_{1 i}$ wisman $_{t-1}$
$+u_{1 t,}$ $\Delta$ pendapatan $_{t}=\delta_{2}$ pendapatan $_{t-1}$

$$
+\sum_{i=1}^{m} \alpha_{2 i} \text { pendapatan }_{t-1}+u_{2 t}
$$

$\Delta \operatorname{harga}_{t}=\delta_{3} \operatorname{harga}_{t-1}+\sum_{i=1}^{m} \alpha_{3 i} \operatorname{harga}_{t-1}+u_{3 t}$.

Untuk menggunakan uji akar unit ADF pada variabel dalam tingkatnya, maka masingmasing variabel disusun hipotesis sebagai berikut:

1. Permintaan pariwisata

$$
H_{0}: \delta_{1}=0 \quad \text { (Permintaan pariwisata }
$$


memiliki akar unit atau tidak stasioner),

$H_{1}: \delta_{1}<0$ (Permintaan pariwisata tidak memiliki akar unit atau stasioner).

2. Pendapatan pariwisata

$H_{0}: \delta_{2}=0 \quad$ (Pendapatan pariwisata memiliki akar unit atau tidak stasioner),

$H_{1}: \delta_{2}<0$ (Pendapatan pariwisata tidak memiliki akar unit atau stasioner).

3. Harga Pariwisata

$H_{0}: \delta_{3}=0$ (Harga Pariwisata memiliki akar unit atau tidak stasioner),

$H_{1}: \delta_{3}<0 \quad$ (Harga Pariwisata tidak memiliki akar unit atau stasioner).

Kriteria penerimaan $H_{0}$ untuk masingmasing hipotesis dari variabel yang diteliti adalah apabila nilai statistik uji $\tau$ lebih besar dari nilai kritis pada tabel DF atau tabel MacKinnon. Adapun hasil uji kestasioneran variabel pada level menggunakan uji akar unit ADF dicantumkan pada Tabel 1.

Tabel 1. Uji Kestasioneran Variabel pada Level

\begin{tabular}{|l|c|c|c|}
\hline \multicolumn{1}{|c|}{ Variabel } & t-statistik & $\begin{array}{c}\text { Nilai } \\
\text { Kritis }\end{array}$ & Prob. \\
\hline $\begin{array}{l}\text { Permintaan } \\
\text { Pariwisata } \\
\text { Australia }\end{array}$ & 0,48927 & $-2,92814$ & 0,9845 \\
\hline $\begin{array}{l}\text { Pendapatan } \\
\text { Wisatawan } \\
\text { Australia }\end{array}$ & $-0,41745$ & $-2,91995$ & 0,8981 \\
\hline $\begin{array}{l}\text { Harga Pariwisata } \\
\text { Australia }\end{array}$ & $-2,61156$ & $-2,91995$ & 0,0973 \\
\hline
\end{tabular}

Berdasarkan hasil uji ADF pada Tabel 1. terlihat bahwa masing-masing variabel tidak stasioner dengan nilai statistik uji $\tau$ lebih besar dari nilai kritis pada tabel DF atau tabel MacKinnon untuk pada $\alpha=5 \%$, dan nilai probabilitas yang lebih besar dari $\alpha=5 \%$.

Memperhatikan bahwa masing-masing variabel tidak stasioner, maka perlu dilakukan proses differencing untuk menghilangkan akar unit yang terdapat pada data. Proses differencing pada orde pertama dilakukan dengan mengambil selisih data pada waktu $t$ dengan data pada waktu $t-1$. Setelah didifferencing kemudian dilakukan uji akar unit ADF pada data hasil differencing untuk mengetahui apakah data tersebut memiliki satu akar unit atau tidak.
Dengan menggunakan uji akar unit ADF, maka data hasil differencing pada orde pertama untuk tiap variabel diasumsikan mengikuti model sebagai berikut:

$\Delta^{2}$ wisman $_{t}=\delta_{4}$ wisman $_{t-1}+\sum_{i=1}^{m} \alpha_{4 i} \Delta^{2}$ wisman $_{t-1}$ $+u_{4 t}$,

$\Delta^{2}$ pendapatan $_{t}=\delta_{5}$ pendapatan $_{t-1}$

$$
+\sum_{i=1}^{m} \alpha_{5 i} \Delta^{2} \text { pendapatan }{ }_{t-1}+u_{5 t}
$$

$\Delta^{2} \operatorname{harga}_{t}=\delta_{6} \operatorname{harga}_{t-1}+\sum_{i=1}^{m} \alpha_{6 i} \Delta^{2} \operatorname{harga}_{t-1}+u_{6 t}$

Untuk menggunakan uji akar unit ADF pada data differencing pertama, maka masingmasing variabel disusun hipotesis sebagai berikut:

1. Permintaan pariwisata

$H_{0}: \delta_{4}=0 \quad(\Delta$ Permintaan pariwisata memiliki akar unit atau tidak stasioner),

$H_{1}: \delta_{4}<0 \quad(\Delta$ Permintaan pariwisata tidak memiliki akar unit atau stasioner).

2. Pendapatan pariwisata

$H_{0}: \delta_{5}=0 \quad$ ( $\Delta$ Pendapatan pariwisata memiliki akar unit atau tidak stasioner),

$H_{1}: \delta_{5}<0$ ( $\Delta$ Pendapatan pariwisata tidak memiliki akar unit atau stasioner).

3. Harga Pariwisata

$H_{0}: \delta_{6}=0 \quad(\Delta$ Harga Pariwisata memiliki akar unit atau tidak stasioner),

$H_{1}: \delta_{6}<0 \quad(\Delta$ Harga Pariwisata tidak memiliki akar unit atau stasioner).

Berikut hasil uji akar unit ADF pada data differencing pertama dicantumkan pada Tabel 2.

Tabel 2. Uji Kestasioneran Data Differencing pertama (I(1))

\begin{tabular}{|l|c|c|c|}
\hline \multicolumn{1}{|c|}{ Variabel } & t-statistik & $\begin{array}{c}\text { Nilai } \\
\text { Kritis }\end{array}$ & Prob. \\
\hline $\begin{array}{l}\Delta \text { Permintaan } \\
\text { Pariwisata } \\
\text { Australia }\end{array}$ & $-3,03108$ & $-2,92814$ & 0,0395 \\
\hline $\begin{array}{l}\Delta \text { Pendapatan } \\
\text { Wisatawan } \\
\text { Australia }\end{array}$ & $-6,99991$ & $-2,92118$ & 0,0000 \\
\hline $\begin{array}{l}\Delta \text { Harga } \\
\text { Pariwisata } \\
\text { Australia }\end{array}$ & $-5,69281$ & $-2,92118$ & 0,0000 \\
\hline
\end{tabular}


Berdasarkan Hasil uji ADF pada Tabel 2. terlihat bahwa masing-masing variabel telah stasioner pada differencing pertama dengan nilai statistik uji $\tau$ lebih kecil dari nilai kritis pada tabel DF atau tabel MacKinnon pada $\alpha=5 \%$, dan nilai probabilitas yang lebih kecil dari $\alpha=5 \%$.

Dari data yang telah stasioner, dapat ditentukan panjang lag yang optimal. Mengingat bahwa estimasi VAR sangat peka terhadap panjang lag yang digunakan, maka berdasarkan uji yang digunakan yaitu Akaike Information Criterion (AIC) diperoleh panjang lag yang yang optimal adalah 3. Hasil panjang lag optimal dicantumkan pada Tabel 3.

Tabel 3. Panjang Lag Optimal

\begin{tabular}{|c|c|}
\hline \multicolumn{2}{|c|}{ Australia } \\
\hline Lag & AIC \\
\hline 0 & 13,04425 \\
\hline 1 & 4,909185 \\
\hline 2 & 5,101204 \\
\hline 3 & $4,485764^{*}$ \\
\hline 4 & 4,529724 \\
\hline
\end{tabular}

* panjang lag optimal

Berdasarkan panjang lag yang diperoleh pada Tabel 3, selanjutnya dilakukan uji kointegrasi. Uji kointegrasi dilakukan untuk melihat suatu hubungan ekuilibrium jangka panjang antara variabel-variabel yang tidak stasioner tetapi memiliki kombinasi linear yang stasioner. Dalam penelitian ini, uji kointegrasi dilakukan dengan menggunakan metode kointegrasi Johansen. Variabel-variabel yang akan diuji harus merupakan variabel yang stasioner pada derajat yang sama. Berikut ini dicantumkan tabel hasil uji kointegrasi dengan metode kointegrasi Johansen pada Tabel 4. dengan hipotesis sebagai berikut:

$H_{0}$ : banyaknya vektor kointegrasi $(r)=0$, $H_{1}$ : banyaknya vektor kointegrasi $(r)>0$.

Apabila nilai trace statistic dan maximum eigenvalue lebih besar dari nilai kritis pada tingkat kepercayaan $\alpha$ adalah $5 \%$ atau nilai probabilitas lebih kecil dari $\alpha$ adalah 5\% maka hipotesis nol ditolak yang artinya terjadi kointegrasi.
Tabel 4. Hasil Johansen's Contegration Test

\begin{tabular}{|c|c|c|c|c|}
\hline \multicolumn{5}{|c|}{ Unrestricted Cointegration Rank Test (Trace) } \\
\hline $\mathrm{H}_{0}$ & $\begin{array}{c}\text { Eigen- } \\
\text { value }\end{array}$ & $\begin{array}{c}\text { Max- } \\
\text { Eigen } \\
\text { Statistic }\end{array}$ & $\begin{array}{c}5 \% \\
\text { Critical } \\
\text { Value }\end{array}$ & Prob. \\
\hline $\mathrm{r}=0 *$ & 0,406817 & 31,15847 & 29,79707 & 0,0346 \\
\hline $\mathrm{r} \leq 1$ & 0,118141 & 6,090317 & 15,49471 & 0,6848 \\
\hline $\mathrm{r} \leq 2$ & 0,001158 & 0,055624 & 3,841466 & 0,8135 \\
\hline \multicolumn{5}{|c|}{ Unrestricted Cointegration Rank Test (Maximum } \\
Eigenvalue) \\
\hline $\mathrm{H}_{0}$ & $\begin{array}{c}\text { Eigen- } \\
\text { value }\end{array}$ & $\begin{array}{c}\text { Max- } \\
\text { Eigen } \\
\text { Statistic }\end{array}$ & $\begin{array}{c}5 \% \\
\text { Critical }\end{array}$ & Palue \\
\hline $\mathrm{r}=0 *$ & 0,406817 & 25,06815 & 21,13162 & 0,0132 \\
\hline $\mathrm{r} \leq 1$ & 0,118141 & 6,034693 & 14,26460 & 0,6088 \\
\hline $\mathrm{r} \leq 2$ & 0,001158 & 0,055624 & 3,841466 & 0,8135 \\
\hline$*$ denotes rejection of the hypothesis at the 0,05 level
\end{tabular}

Berdasarkan Tabel 4. dapat dilihat bahwa nilai trace statistic dan maximum eigenvalue pada $r=0$ lebih besar dari critical value dengan tingkat signifikansi $5 \%$ dan nilai probabilitasnya lebih kecil dari $\alpha=5 \%$. Hal ini berarti hipotesis nol yang menyatakan bahwa tidak ada kointegrasi ditolak dan hipotesis alternatif yang menyatakan bahwa ada kointegrasi tidak dapat ditolak atau dengan kata lain, terindikasi berkointegrasi, yaitu satu kointegrasi.

Dengan demikian, hasil uji kointegrasi untuk mengindikasikan bahwa di antara permintaan pariwisata Australia, pendapatan wisatawan Australia, dan harga pariwisata Australia memiliki hubungan keseimbangan jangka panjang. Berikut hasil taksiran koefisien jangka panjang pada pengujian kointegrasi antara permintaan pariwisata Australia, pendapatan wisatawan Australia, dan harga pariwisata Australia:

\begin{tabular}{|l|l|}
\hline 1 Cointegrating Equation(s): $\quad$ Log likelihood $-72,75853$ \\
\hline \hline $\begin{array}{l}\text { Normalized cointegrating coefficients (standard error in } \\
\text { parentheses) } \\
\text { WISMAN_AUS }\end{array}$ \\
$\begin{array}{l}\text { PENDAPATAN_ HARGA_AUS } \\
1,000000\end{array}-23722,27$ & $-1,20 \mathrm{E}+11$ \\
\hline
\end{tabular}


persamaan kointegrasi yang terbentuk adalah:

$$
\begin{aligned}
& \text { wisman_aus }_{t}=23722,27 * \text { pendapatan_aus }{ }_{t} \\
& +1,20 \\
& \times 10^{11 * \text { harga_aus }_{t}}
\end{aligned}
$$

Dari persamaan kointegrasi, dapat diketahui bahwa variabel-variabel bebas yang terdapat pada persamaan (10) dalam jangka panjangnya memberikan pengaruh terhadap permintaan pariwisata Australia sebesar koefisien dari masing-masing variabel tersebut.

Berdasarkan persamaan (10), diperoleh bahwa, pendapatan wisatawan Australia dan harga pariwisata Australia memberikan pengaruh yang positif terhadap permintaan pariwisata Australia. Hal ini berarti bahwa semakin meningkatnya pendapatan wisatawan Australia dan harga pariwisata Australia, akan mengakibatkan jumlah permintaan pariwsata Australia semakin bertambah. Dalam hubungan ini, peningkatan pendapatan wisatawan mampu meningkatkan permintaan pariwisata apabila komoditi pariwisata yang digunakan oleh wisatawan merupakan barang normal (Stabler, et al [9]). Di sisi lain, walaupun harga pariwisata meningkat, permintaan pariwisata akan tetap meningkat, hal ini dapat dipegaruhi oleh faktor-faktor lainnya, seperti: pendapatan wisatawan Australia yang meningkat, taraf hidup yang berbeda, jarak antara Australia dengan Bali yang dekat, harga pariwisata negara lain lebih mahal, dan jumlah penduduk yang bertambah; tanpa menghiraukan harga pariwisata itu sendiri.

Berdasarkan panjang lag dan hasil uji kointegrasi yang diperoleh, selanjutnya akan dilakukan estimasi VAR yang kemudian diresepresentasikan ke dalam bentuk VECM. Untuk mengkonstruksi persamaan VECM maka variabel-variabel yang akan dimasukkan dalam model haruslah di-differencing. Bentuk persamaan VECM pada persamaan adalah:

$\Delta$ wisman_aus ${ }_{t}=9623,446+$

$0,054716 * \Delta$ wisman_aus $s_{t-1}-$

$0,745698 * \Delta$ wisman $_{\text {aus }_{t-2}}+$

$0,042703 * \Delta$ wisman $_{\text {aus } t-3}-$
1091,000* pendapatan $_{\text {aus }_{t-1}}-$

$293,2022 * \Delta$ pendapatan $_{\text {aus }_{t-2}}+$

$182,4489 *$ pendapatan $_{\text {aus } t-3}-$

$7,90 \times 10^{8} * \Delta$ harga $_{\text {aus } t-1}-$

$6,28 \times 10^{8} * \Delta$ harga $_{\text {aus } t-2}-$

$4,50 \times 10^{8} *$ harga $_{\text {aus } t-3}-$

$0,006729 * \mathrm{ECT}_{\mathrm{t}-1}$

Berdasarkan hasil dari VECM diperoleh bahwa nilai probabilitas ECT yaitu 0,0042. Nilai ini kurang dari nilai $\alpha$ yang digunakan yaitu 5\%, sehingga dapat disimpulkan bahwa variabel ECT signifikan. Ini berarti bahwa persamaan (11) merupakan model yang valid untuk menggambarkan dinamika jangka pendek.

Berdasarkan persamaan (11), diketahui bahwa koefisien ECT sebesar -0,006729. Hal ini berarti bahwa pada periode sebelumnya $t-1$, permintaan pariwisata Australia kekurangan hubungan keseimbangannya, sehingga pada waktu $t$ harus bertambah sebesar 0,006729 agar kembali ke arah keseimbangannya. Mengingat bahwa data yang digunakan adalah data kuartal, maka lamanya waktu yang diperlukan untuk kembali ke kondisi keseimbangannya adalah 0,006729 kuartal atau lebih kurang 0,6 hari (dengan mengambil banyaknya hari dalam satu kuartal adalah 90 hari).

Berdasarkan persamaan (11), diperoleh bahwa permintaan pariwisata Australia yang sudah di-differencing satu kali pada waktu ke- $t$ akan dipengaruhi oleh sebuah konstanta yaitu rata-rata sebesar 9623,446. Permintaan pariwisata Australia juga dipengaruhi oleh dinamika pergerakan dirinya sendiri pada tiga periode sebelumnya, dengan koefisien permintaan pariwisata Australia terbesar terdapat pada satu periode sebelumnya dan koefisien permintaan pariwisata Australia terkecil terdapat pada dua periode sebelumnya. Permintaan pariwisata Australia secara umum memberikan pengaruh yang posistif terhadap pergerakan dirinya sendiri.

Pendapatan wisatawan Australia memberikan pengaruh yang negatif dalam jangka pendek terhadap permintaan pariwisata 
Australia. Pengaruh yang diberikan terhadap permintaan pariwisata Australia adalah sebesar koefisien pada tiap periodenya, dengan koefisien pendapatan wisatawan Australia terbesar terdapat pada tiga periode sebelumnya dan koefisien pendapatan wisatawan Australia terkecil terdapat pada satu periode sebelumnya. Hal ini tidak sejalan dengan pengaruh yang diberikan dalam jangka panjang. Artinya, peningkatan pendapatan wisatawan Australia akan mengakibatkan jumlah permintaan pariwisata Australia akan semakin menurun. Menurut Stabler et al. [9], dalam hubungan ini peningkatan pendapatan wisatawan menurunkan permintaan pariwisata apabila komoditi pariwisata ini merupakan barang inferior. Hal ini dapat terjadi pada daerah tujuan wisata massal yang pada saat pendapatannya meningkat, justru wisatawan tidak akan memilih daerah tersebut sebagai tujuan wisata tetapi akan memilih daerah tujuan wisata lain yang privasinya lebih tinggi.

Hasil yang sama diperoleh seperti pendapatan wisatawan Australia, harga pariwisata Australia juga memberikan pengaruh yang negatif dalam jangka pendeknya terhadap permintaan pariwisata Australia. Hal ini tidak sejalan dengan pengaruh yang diberikan dalam jangka panjang. Dalam jangka pendek, pengaruh yang diberikan terhadap permintaan pariwisata Australia adalah sebesar koefisien pada tiap periodenya, dengan koefisien harga pariwisata Australia terbesar terdapat pada tiga periode sebelumnya dan koefisien harga pariwisata Australia terkecil terdapat pada satu periode sebelumnya. Hal ini mengindikasikan bahwa hubungan antara harga pariwisata Australia dan permintaan pariwisata Australia berlawanan arah. Artinya, peningkatnya harga pariwisata Australia akan berkontribusi pada penurunan jumlah permintaan pariwisata Australia, dan sebaliknya. Hal ini terjadi pada saat nilai tukar rupiah menguat, akan meningkatkan harga pariwisata Indonesia, sehingga berakibat pada penurunan jumlah kunjungan wisman. Sebaliknya, pada saat rupiah melemah, harga pariwisata Indonesia menjadi menurun dan jumlah kunjungan wisman akan meningkat.

\section{KESIMPULAN}

Penelitian ini menyimpulkan bahwa berdasarkan uji kointegrasi diperoleh dalam hubungan jangka panjang, pendapatan wisatawan Australia dan harga pariwisata Australia memberikan pengaruh yang positif terhadap jumlah permintaan pariwisata Australia, sedangkan berdasarkan Vector Error Correction Model, diperoleh dalam hubungan jangka pendek, pendapatan wisatawan Australia dan harga pariwisata Australia memberikan pengaruh yang negatif terhadap jumlah permintaan pariwisata Australia.

\section{DAFTAR PUSTAKA}

[1] Box, G. \& Jenkins, G., 1970. Time Series Analysis: Forecasting and Control. San Fransisco: Holden Day.

[2] Dickey, D. A. \& Fuller, W. A., 1981. Likelihood Ratio Statistics for Autoregressive Time Series With a Unit Root. Econometrica, Volume 49, pp 10521072.

[3] Enders, W., 2004. Applied Econometric Time Series. New York: John Wiley \& Sons, Inc.

[4] Engle, R. F. \& Granger, C. W. J., 1987. Co-Integration and Error Correction: Representation, Estimation, and Testing. Econometrica, Volume 55, pp. 251-276.

[5] Gujarati, D. N., 2004. Basic Econometrics. New York: The McGraw-Hill.

[6] Johansen, S. \& Juselius, K., 1990. Maximum Likelihood Estimator and Inference on Cointegration with Applications to the Demand for Money. Volume 52, pp 169-210.

[7] Sims, C. A., 1980. Macroeconomics and Reality. Econometrica, Volume 48, pp. 148.

[8] Song, H., S. F. W. \& Li, G., 2008. The Advanced Economics of Tourism Demand. London: Routledge.

[9] Stabler, M., Papatheudorou, A. \& Sinclair, M. T., 2010. The Economic of Tourism. London: Routledge.

[10] Tsay, R., 2002. Analysis of Financial Time Series. United States of America: John Wiley \& Sons Inc. 